\title{
Exerc ising Local-Wisdom-based Character Education in Madrasah: an Ethnographic Study in a Madrasah in Sambas, West Kalimantan
}

\author{
Purniadi Putra ${ }^{\text {a) }}$, Aslan $^{\text {b) }}$ \\ a) Institut Agama Islam Sultan Muhammad Syafiuddin Sambas \\ b) Institut Agama Islam Sultan Muhammad Syafiuddin Sambas
}

\section{ABSTRAK}

Pengaruh budaya hedonistik telah menggiring pada krisis karakter di berbagai mayarakat di nusantara. Kearifan lokal dengan pluralitas, toleransi, dan gotong royong, seolah-olah menjadi anti-tesa dari kehidupan yang hedonistik. Dari sini, berbagai pemikiran muncul tentang pentingnya membina pendidikan karakter berdasarkan kearifan lokal di lembaga pendidikan Islam. Dengan pendekatan etnografis, penelitian ini mengeksplorasi penerapan upaya pembinaan karakter di madrasah di Sambas yang berbasis pada unsur-unsur budaya local. Hasil penelitian menunjukkan bahwa penggunaan pakaian teluk belanga' dan baju kurung berkontribusi pada pembentukan perilaku keislaman, jiwa sosial, dan sikap penghargaan pada budaya lokal.

\section{ABSTRACT}

The influence of hedonistic culture has led to a character crisis in various societies in the archipelago. Local wisdom with plurality, tolerance, and mutual cooperation, seems to be the anti-thesis of a hedonistic life. From here, various thoughts emerge about the importance of fostering character education based on local wisdom in Islamic education institutions. With an ethnographic approach, this study explores the application of character building efforts in madrasas in Sambas which are based on local cultural elements. The results showed that the use of 'Teluk belanga' and kurung clothes contributed to the formation of Islamic behavior, social life, and respect for local culture.

\section{KATA KUNCl}

Pendidikan Karakter; Kearifan Lokal; Etnografi; Madrasah Ibtidaiyah

\section{KEYWORDS}

Character Education; Local Wisdom; Ethnography; Madrasah Ibtidaiyah

\section{A. Introduction}

Various social phenomena that occur at this time is very worrying, from various conflicts of moral ethical life degradation that occur in Indonesia in varying scope. According to ${ }^{1}$, there are 10 indications of a decline in consciousness that is happening in the community at this time including: (a) violence and anarchy, (b) acts of theft, (c) fraudulent acts, (d) neglect of the applicable rules, (e) brawls between students, (f) intolerance, (g) the use of bad language, (h) premature sexual maturity and irregularities, and (i) self-destructive behavior.

in adition, from the $2015 \mathrm{KPAl}$ data, it was noted that cases of children who became perpetrators violence experienced an increase, among them in 2014, there were 67 cases of children who became perpetrators of violence. Whereas in 2015, there were 79 cases. In addition, children as brawlers increased from 46 cases in 2014 to 103 cases in 2015. This is consistent with the results of research

\footnotetext{
${ }^{1}$ Thomas Lickona, Thomas Lickona, Educating for Character; Mendidik untuk Membentuk Karakter (Jakarta: Bumi Aksara, 2015).
} 
Safaria, Tentama, \& Suyono ${ }^{2}, 83 \%$ of high school students in Indonesia cybervictimization experience and almost every day both in cyberspace and in schools call calls with ridicule, experiencing rumors/gossip,threats, sexual harassment and relationship with problems privately using social media.

The case is caused by the failure of modernism which is marked by the existence of rationalism, materialism and capitalism which are supported by technological and scientific developments that lead to religious moral disorientation with the collapse of human dignity According to Fu, Jean Hoying \& Chiu, Chi Yue ${ }^{3}$, globalization has transformed a world culture that is prone to consumerism, hedonism and materialism. Today's global culture has occurred including the hegemonization of lifestyle (life style) which sparked various creations and facilities to facilitate the sophisticated human needs of human creations that stream new values from the outside, namely the circulation and exchange of culture.

Based on the phenomena that occur above the Republic of Indonesia Presidential Regulation as a civilized nation is a country that upholds noble character, noble values, wisdom, and character in realizing a civilized nation through the strengthening of religious values, honesty, tolerance, discipline, hard work, creative, independent, democratic, curiosity, national spirit, love of the motherland, respect for achievement, communicative, peace-loving, fond of reading, caring for the environment, caring socially, and responsible, then strengthening character education is a shared responsibility of the family, education unit, and the community. ${ }^{4}$

According Zulkarnain Adrian Widisono, "The Local Wisdom on Sasak Tribe Sade Hamlet Central Lombok Regency," Local Wisdom : JurnallImiahKajianKearifanLokal 11, no. 1 (January 16, 2019): 42-52, accessed January 9, 2020, http://jurnal.unmer.ac.id/index.php/lw/article/view/2711. Local wisdom is a principle and way that is understood, adhered to, andapplied by the local community with its environment that is transform into customary values andnorms. According to Stoll ${ }^{5}$, schoolculture is integrated with customs, rituals, symbols, stories, and language, "artifacts" of culture.In the context of this research to solve the problems that occur due to the rapid flow of globalization, the elements of local wisdom integrated character education is a good thing to offset the negative effects of capitalism and globalization in today's kids. The element of local wisdom contained in learning, character education is integrated in the learning process and curriculum. In addition, the existence of an element of local wisdom will always be maintained and remain sustainable which is implemented in concrete everyday life as part of school culture.

Value is something that is held in high esteem that can color and animate one's actions. Values are more than just beliefs, values always involve mindset and action, so there is a very close relationship

\footnotetext{
${ }^{2}$ Achmad Faqihuddin, 'Internalisasi Nilai-Nilai Humanistik Religius pada Generasi Z', Edukasia : Jurnal Penelitian Pendidikan Islam, 12.2 (2017), 263

${ }^{3}$ Hatamar Rasyid, "Nilai-Nilai Kearifan Lokal dalam Pengembangan Pendidikan Karakter di Era Global," Edugama 1, No. 1 (2015): 31.

4Peratuan Presiden, "Peraturan Presiden Republik Indonesia Nomor 87 Tahun 2017 Tentang Penguatan Pendidikan Karakter," 2017.

${ }^{5}$ Mahfud Junaedi and Fatah Syukur, "Moral Education in Japanese Schools a Model for Improving Character Education In Indonesia," Analisa Journal of Social Science and Religion 2, No. 1 (2017): 23-40.
} 
between values and ethics. ${ }^{6}$ Local wisdom, which is owned by the Sambas Malay community, shows a culture of shame that reflects prestige (authority), an emphasis on honor, reputation, and self-esteem rather than a culture of guilt. The Sambas Malay community expresses it in the terminology of suppan which means shame, don't try touppane 'insanak, which means not to do something that is embarrassing to the family. The social life of the village community is more characterized by the values of solidarity or brotherhood. Villagers in the Sambas Malay community generally uphold the values of mutual cooperation, consensus, simple living, caring for one another and applying local pepatih customs. Therefore, the special character of the Sambas Malay character in social relations is known as belale 'or mutual cooperation. ${ }^{7}$

In principle MIN 2 Sambas has a child-friendly school program designated by the Office of Women's and Children's Empowerment and from the Ministry of Religion to be an example in Sambas District. The location of MIN 2 Sambas is one of the schools that has achievements in both the academic and non-academic fields, such as national school competitions and adwiyata schools. Thus from the background of these achievements the concept of character education has indeed been applied in Madrasah Ibtidaiyah Negeri 2 Sambas.

Edgar Suratman in Anas Salahudin stated, many things could be achieved by utilizing and preserving local culture. Local arts and culture that contain noble values of the community can become a glue between social groups with diverse backgrounds so that social conflicts can be avoided. Based the results of Rasyid ${ }^{8}$, research that local wisdom can function as a source of noble values for this purpose.

The importance of intellectual character education in the development of noble character has pedagogical implications so that theorists and practitioners who explore the exemplary approach to intellectual character education must pay attention to special cases of high student curiosity. ${ }^{9}$

Madrasah Ibtidaiyah Negeri 2 Sambas integrates local wisdom in the implementation of activities in madrasas, such as; Sambas Malay regional arts include the use of the Sambas Malay language in the learning process, raddat koko dance, bay gown clothes and brackets. Thus educational institutions at the elementary level of Islam can prepare students to face the flow of social change that is so large today by preserving local culture is expected to reintroduce local culture of Malay Sambas to elementary age children so they can learn the meaning of life and stories that have character values.

In this study the focus of Sambas local wisdom-based character education fosters character education in MIN 2 Sambas Regency, West Kalimantan with the focus of the study is (1) how is character education based on local wisdom in Sambas Sambas 2 MIN West Kalimantan? and (2) What

\footnotetext{
${ }^{6}$ Maisyanah and Lilis Inayati, "Internalisasi Nilai-Nilai Pendidikan Agama Islam pada Tradisi Meron," Edukasia: Jurnal Penelitian Pendidikan Islam 13, No. 2 (2018): 287-308.

${ }^{7}$ Endang Susilawati and Asmah Haji Omar, "Makna Sosial dalam Kata Panggilan: Kajian Etnografi Komunikasi dalam Komuniti Bahasa Melayu Sambas," Social Meaning in Address Form 28, No. 1 (2011).

${ }^{8}$ Rasyid, "Nilai-Nilai Kearifan Lokal dalam Pengembangan Pendidikan Karakter Di Era Global."

${ }^{9}$ Lani Watson, "Educating For Inquisitiveness: A Case Against Exemplarism For Intellectual Character Education," Journal Of Moral Education 48, No. 3 (July 3, 2019): 303-315.
} 
are the implications of character education based on local wisdom on the religious behavior of students in MIN 2 Sambas, Sambas Regency, West Kalimantan? While the purpose of this study is to describe and look for the meaning of describing and analyzing local wisdom-based character education in MIN 2 Sambas, West Kalimantan and describing and analyzing the implications of local wisdombased character education on the religious behavior of students in MIN 2 Sambas, West Kalimantan.

\section{B. Theoretical Frameworks}

Education is a system that is programmed in developing the potential of students, so that it will produce ways of thinking, having values, morals, and beliefs inherited by the community and developing the legacy in accordance with the context of present and future life. While the character is the character, character, character, or personality of a person that is formed from the results of internalizing various policies (virtues) that are believed and used as a basis for perspective thinking, acting and acting. ${ }^{10}$

According to Lickona ${ }^{11}$, stated Moral are the foundation upon which a country rises to great heights. Take away morals and individuals, leaders, and countries fall (old spiritual wisdom). According to Baharun \& Ummah (Herwin Sutrisno dkk.,2019) in other ways, students' character in the teaching and learning process is an important thing. It can be made the learning process would be meaningfullearning. Islamic character's perspectives make the student understand what theyhad taught and how to implement in daily life activities.

In this context Kulsum ${ }^{12}$ values and characters are formally formulated for the functions and goals of national education, students must have character in order to face life's challenges and be members of a community that has superior personality. Whereas according to Michael Hand ${ }^{13}$, moral education aims to be able to realize children follow moral standards and believe that they can be justified which makes sense and disagreement about them, indoctrination. Success in character education depends on supporting components including staff, special curriculum, and between systems (character values). Competent school staff are critical in determining the success of character education. In addition, implementing the character building involves all parties in the school. ${ }^{14}$

While in the context of Islamic education according to Kamrani ${ }^{15}$ character education is very closely related to Islamic education because of the growth and development of divine values in children including the divine values of imaniah, ubudiyah and muamalah. Divine values in this child will form individual traits that will provide guidelines for good behavior.

\footnotetext{
${ }^{10}$ Kementerian Pendidikan Nasional Badan Penelitian dan Pengembangan Pusat Kurikulum, Pengembangan Pendidikan Budaya dan Karakter Bangsa (Jakarta: Kementerian Pendidikan Nasional, 2010).

${ }^{11}$ Abdullah Hamid, Pendidikan Karakter Berbasis Pesantren; Pelajar dan Santri dalam Era IT \& Cyber Culture (Surabaya: Imtiyaz, 2017).

${ }^{12}$ Siswanto Siswanto Et Al., "Environmental Cultured Education and Its Implication on the Student's Competencies in an Adiwiyata School," Jurnal Cakrawala Pendidikan 38, No. 3 (October 24, 2019): 552-564.

${ }^{13}$ Michael Hand, "Moral Education and the Justification of Basic Moral Standards: Replies to Clayton, Stevens and D'olimpio," Journal of Moral Education 48, No. 4 (October 2, 2019): 529-539.

${ }^{14}$ Sukadari Sukadari, Suyata Suyata, and Shodiq A. Kuntoro, "Penelitian Etnografi Tentang Budaya Sekolah dalam Pendidikan Karakter di Sekolah Dasar," Jurnal Pembangunan Pendidikan: Fondasi dan Aplikasi 3, No. 1 (July 1, 2015): 58-68.

${ }^{15}$ Kamrani Buseri, Dasar, Asas dan Prinsip Pendidikan Islam (Banjarmasin: Iain Antasari, 2014).
} 
Education that develops character is education that can help develop ethics, morals, and responsible attitudes by providing compassion, showing and teaching good character to students. ${ }^{16}$ Meanwhile ${ }^{17}$, culture is defined as a set of systems of thought, values, morals, norms, and beliefs produced bythe community. Thus systems of thought, values, morals, norms, and beliefs are the result of human interaction with each other and their natural environment.

The benefits of local culture in the field of education ${ }^{18}$ revealed that the framework for the utilization of local cultural values can be done by various cultural institutions that can be utilized in the community. Among them by inviting students to watch art performances in the community, involving students in various cultural activities, inviting students to show various cultural communities, such as folk songs, wearing traditional clothing, introducing cultural heritage in art in the community or playing games in the community.

According Hardati ${ }^{19}$, parents are local products that better understand the meaning of local wisdom involved in tourism activities in the region with the aim of fostering interaction and developing cultural values in shaping children's character.In line with that according to Moest ${ }^{20}$ the importance of culture and inheritance for students namely knowledge and appreciation of their own heritage and culture and teenagers learn best when the curriculum is set according to the context of experience, location, and culture. Local wisdom as a tool of knowledge in a community, both those from previous generations and from their experiences relating to the environment and other communities, to resolve properly the various problems and / or difficulties encountered. ${ }^{21}$

Ideally, cultural contact with various cultures can produce collaboration and innovation. The indirect side, contact between various cultures can produce conflict and war. $^{22}$ In this case character education will be very effectively applied, if the values taken there are factors of social, culturaland religious closeness of students. In other words, the internalized character values are cultural values on a daily basis that they know and understand, making it easier for them to make a basis for acting in everyday life. ${ }^{23}$

\footnotetext{
${ }^{16}$ Mohamad Erihadiana, "The Implementation of Islamic Local Content in Building Character Education at Junior High Shcool Al Amanah Bandung," Jurnal Pendidikan Islam 4, no. 2 (January 25, 2019): 41-50, accessed January 17, 2020, https://journal.uinsgd.ac.id/index.php/jpi/article/view/3812.

${ }^{17}$ Sunahrowi Sunahrowi, Anastasia P, and Singgih K, " Religiosity and Local Wisdom in Teaching Cultural Science in Faculty of Languages and Arts of Semarang State University," IBDA : Jurnal Kajian Islam dan Budaya 16, no. 2 (November 1, 2018): 262-275, accessed January 15, 2020, http://ejournal.iainpurwokerto.ac.id/index.php/ibda/article/view/1686.

${ }^{18}$ Abuddin Nata, Sosiologi Pendidikan Islam (Jakarta: PT Rajagrafindo Persada, 2014).

${ }^{19}$ Trisna Handayani, Etty Soesilowati, and Agustinus Sugeng Priyanto, "Student Character Buliding Reconstruction Junior High School in District Galesong Takalar Based Values National Culture," Journal of Educational Social Studies 7, No. 2 (2018): 116 - 122.

${ }^{20}$ Merethe Skårås, Tami Carsillo, and Anders Breidlid, "The Ethnic/Local, the National and The Global: Global Citizenship Education in South Sudan," British Journal of Educational Studies (April 5, 2019): 1-21.

${ }^{21}$ I Made Purna, “Local Wisdom Of Mbawa Village Society in Building Religious Tolerance," Jurnal Pendidikan dan Kebudayaan 1, No. 2 (2016): 17.

${ }^{22}$ Mitchel Vinco, Nana Supriatna, and Agus Mulyana, "The Development Of 21st Century Cultural Intelligence through Discovery Learning and First-Person Historical Presentation" (2019): 11.

${ }^{23}$ Agus Wibowo and Gunawan, Pendidikan Karakter Berbasis Kearifan Lokal di Sekolah (Yogyakarta: Pustaka Pelajar, 2015).
} 
Sambas Malay is one of the Malay sub-ethnic groups that has a specificity in terms of language, customs, arts, and so forth. Indigeneous people are defined as groups of people who have ancestral ancestors in a particular geographical area, and have their own values, ideology, economic, political, cultural, social and regional systems. ${ }^{24}$ The Sambas Malay is administratively a new tribe that emerged in the 2000 Population Census and accounts for $12 \%$ of the population of West Kalimantan. Previously, the Sambas were incorporated into the Malay Tribe at the 1930 Population census. In connection with this, the possibility of the "Sambas Malay Dialect" increased from a dialect to a tribal language, the Sambas Tribal Language.

In the old theory pioneered by Kern in Hermansyah ${ }^{25}$ stated that the migration of Ancient Malay to the Archipelago originated from Champa, Chocin-China (Indochina), Cambodia and its surroundings continued to the Malay Peninsula and spread to other regions in the Archipelago. Language and archeological evidence shows that Ancient Austronesian migration which originated in Malay actually originated from Taiwan to the Philippines and continued to Kalimantan through the north of the Philippines.

The hallmark of the Sambas Malay community is that traditional societies are open in the sense of upholding tradition, carried out from generation to generation and accepting foreign cultures as long as they do not conflict with Islamic teachings and existing traditions. One form of openness of the Sambas Malaycommunity is the Malay "claim" to other ethnic groups, when the ethnic group mingles, lives together in the community and is Muslim, even if there are ethnic non-Muslims, then converts to Islam (converts) by reason of marriage or other reasons, then it is usually declared as Malay. ${ }^{26}$

The closeness of Islam and Malay imagery with two inseparable currencies, one part will not have meaning if there is no other part. Someone is said to be Malay if he is Muslim. This statement shows that Islam is a differentiator between Malay and non-Malay. ${ }^{27}$ According to E. L. Earnshaw ${ }^{28}$ diverse attitudes are observant behaviors in religion which means tolerating other people's religious practices and promoting interfaith harmony. Religion is defined as observing and practicing religious norms diligently but also being tolerant and open.

In classical Islamic madrasa is a learning institution par excellence, in this case devoted to the study of Islamic law, the queen of Islamic sciences. In Southeast Asia, pesantren and madrasa have three functions; first, as a center for transmitting religious knowledge; second, as guardians of Islamic traditions, third; as a center of reproduction 'ulama. Thus, the main purpose of madrasas is to provide

\footnotetext{
${ }^{24}$ Rizal Muntansyir, Kearifan Lokal Masyarakat Melayu dalam Tinjauan Filosofis, Legenda Rakyat, Filosofis Air, Dan Tradisi (Yogyakarta: Fakultas Filsafat, Universitas Gadjah Mada, 2016).

${ }^{25}$ Hermansyah, Melayu dan Islam Borneo (Pontianak: Iain Pontianak, 2015).

${ }^{26}$ Alkadri, Bunga Rampai Seni, Budaya \& Sejarah Pejuang Sambas (Pontianak: Top Indonesia, 2017).

${ }^{27}$ Sunandar, "Melayu dalamTantangan Globalisasi: Refleksi Sejarah dan Berubahnya Sistem Referensi Budaya," Khatulistiwa-Journal of Islamic Studies 5, No. 1 (2015): 60-73.

${ }^{28}$ Faizah Binti Awad, "Muslim Cultural Identity and Attitude Change Among Tolakinese Comunity in Kendari," Journal of Indonesian Islam 10, No. 2 (December 1, 2016): 355.
} 
students with a knowledge system in knowing their God. ${ }^{29}$ Islamic education institutions are expected to become one of the forces that can contribute to the formation of a new Indonesian culture based on transedental values that will be a reference to guide the public in combating destructive value distortions, culture of Indonesian society. ${ }^{30}$

Characteristics of elementary school level children have a relationship in dressing according to psychological development in the level of feeling more sensitive children. Feelings of shame andpride give effect to the child's view of the individual so that the child's awareness is higher in adapting about emotions to culture. ${ }^{31}$

The age of elementary school children can follow the rules of regulation of both parents or social environment in the community so that children tend to understand some of the reasons that cause these regulations. In addition, children can process in the form of behavior with the concept of right or wrong or good or bad. Whereas in elementary school age the development of religious appreciation is characterized by (a) religious attitudes that are accepting accompanied by understanding, (b) the views and understandings of God are obtained rationally based on the formulation of logic that is guided by the indicators of the universe as an embodiment of His majesty and (c) spiritual appreciation deepened, the implementation of ritual activities was accepted as amoral attitude. ${ }^{32}$

\section{Methods}

This research uses an ethnographic approach and interpret the culture of social groups or systems. Ethnography is an empirical and theoretical approach that aims to get a description and indepth analysis of culture based on intensive field research. ${ }^{33}$ Spradley $^{34}$ says that the core of ethnography is an effort to pay attention to the meaning of the actions of events that happen to people we want to understand. Meanwhile, ${ }^{35}$ said that "ethnography is a qualitative design in which the researcher describes and interprets the shared and learned patterns of values, behaviors, beliefs, and language of a culture-sharing group. Ethnographic studies (ethnographic studies) describe and interpret the activities and cultures that exist in MIN 2 Sambas, West Kalimantan. This research was conducted in MIN 2 Sambas Regency in rural areas Sekuduk District Sambas District Sambas West Kalimantan learning process in class, local arts, extracurricular and $\mathrm{O} 2 \mathrm{~S}$ competitions at district and provincial level.

This study uses an ethnographic approach and interpreting the group culture or social system. Ethnography is an empirical and theoretical approach that aims to obtain a deep cultural description

\footnotetext{
${ }^{29}$ Kamaruzzaman Bustamam Ahmad, "Educational Practice: Lessons to be Learned from Madrasah and Religious Schools in Contemporary Southeast Asia," Indonesian Journal of Islam and Muslim Societies 5, No. 1 (June 1, 2015): 29.

${ }^{30}$ Djamudin, dkk., "Kajian dan Pengembangan Pembinaan Pendidikan pada Madrasah: Studi Kebijakan Pembinaan Madrasah Era Desentralisasi dan Otonomi Daerah," Edukasi: Jurnal Penelitian Pendidikan Agama dan Keagamaan 5, No. 3 (2017): 68-75.

${ }^{31}$ Christiana Hari Soetjiningsih, Perkembangan Anak; Sejak Pembuahan Sampai dengan Kanak-Kanak Akhir (Jakarta: Prenada, 2014).

${ }^{32}$ Syamsu Yusuf, Psikologi Perkembangan Anak dan Remaja (Bandung: PT Remaja Rosdakarya, 2012).

${ }^{33}$ Barker Chris, Cultural Studies: Teori dan Praktik. Terj. Nurhadi (Yogyakarta: Kreasi Wacana, 2006).

${ }^{34}$ Sukadari, Suyata, and Kuntoro, "Penelitian Etnografi tentang Budaya Sekolah dalam Pendidikan Karakter di Sekolah Dasar."

${ }^{35}$ John W. Creswell, Qualitative Inquiry \& Research Design Choosing among Five Approaches (London: Sage Publications, 2007).
} 
and analysis based on intensive field research. Spradley said that the essence of ethnography is an attempt to pay attention to the meaning of the actions of events that occur to the people we want to understand. While ethnography is a qualitative design where the researcher describes and interprets the patterns of values, behavior, beliefs, and language that are learned together from a shared cultural group. Ethnographic studies (ethnographic studies) describe and interpret the activities and culture that exist in MIN 2 Sambas, West Kalimantan Research This was carried out at MIN 2 Sambas Regency in the villages of Sekuduk District, Sambas District, Sambas Regency, West Kalimantan, the learning process in class, regional arts, extracurricular activities and $\mathrm{O} 2 \mathrm{~S}$ competitions at district and provincial levels.

MIN 2 Sambas is equivalent to a State Elementary School which is unique under the Ministry of Religion, namely the preservation of local wisdom such as the special Sambas Melayu Sambas dance in Sekuduk Village with the value of Islamic education, namely friendship because during the Dutch colonial period people were prohibited from gathering, mutual cooperation (belalle') in cleans schools, has a high-end playground, uses the Malay Sambas language, and wears the gulf bay 'and the Sambas Malay brackets.

The ethnographic research procedure is cyclical which includes six steps; including; (a) select an ethnographic project, (b) ask ethnographic questions, (c) collect ethnographic data, (d) take ethnographic records, (e) analyze ethnographic data, (f) write ethnographic reports. Technically, the procedure for using data collection in data collection in this research is (a) primary observation, namely direct observation of the activities and processes of cultural learning at MIN 2 Sambas which is located in Kampung Sekuduk which has many local cultures; (b) Exploratory interviews related to the Malay Sambas oral tradition in the MIN 2 Sambas learning process.

In qualitative research data collection techniques, researchers are needed as an instrument. This is done through the process of collecting data by observation, the instrument used is field notes. In the process of collecting data through interviews, the instruments used were a list of questions and transcriptional data. In the collection process, the primary data sources were teachers and community leaders, especially the school committee, while the secondary data sources were documents related to local culture, journals, photos of students' activities in wearing Sambas Malay clothes. Retrieval of data through documents, the instrument used is data recording. Researchers as instruments are needed because researchers as subjects must be close to the object of their research to obtain objective research quality. Researchers as an instrument will be more responsive, adaptive, emphasize holistic (comprehensive understanding), expansive, and understand data in the context of the field.

\section{Discussion}

\section{Belanga Bay Clothing and Sambas Melayu Kuras Shirt in Character Education}

Efforts to explore the character values of MIN 2 Sambas students, especially the Sambas Malay from every sphere of community life including; Traditional Sambas, language and arts of the Sambas 
Malay region are implemented MIN 2 Sambas Regency with the aim of restoring the distinctiveness of Sambas Malay culture by integrating learning of Islamic educational values from students' daily culture, raddat koko dance art in extracurricular programs in madrasas. The implementation of character education based on local wisdom is very important to be practiced in every part of life both in academic activities and strengthening at home and the local culture of the community in the neighborhood where students live. Every aspect of activities planted in madrasah as well as in the family and community environment must provide a good picture of character, so that they can become character agents for themselves and others.

In the implementation of cultured character education from the existence of local wisdom, the Sambas Malay residence functions as a shaper and reinforcer of tribal identities, local Sambas Malay wisdom can be used as a filtering for values that originate from the outside and serve as a foothold in developing noble values to be internalized. In character education especially in madrassas.The implementation of character education based on local wisdom applied in MIN 2 Sambas Regency is reflected in the use of bay gowns and brackets. The use of bay gowns and clothes brackets has features including feeling proud in wearing typical Sambas Malay clothes meaning showing the love of the region. Besides that politeness is also seen from a true Muslim. Through the meaning of the clothes of the bay gown and the brackets as an introduction to the symbol, the meaningfulness of the character's value with a sense of love for their own region and a sense of politeness in adab dress. This is in accordance with the code of ethics MIN 2 Sambas is characterized by Islam politely and politely so that the use of bay gowns and clothes brackets is very compatible with the culture of madrasas and local culture of the religious Sambas Malay community. The tradition of Sambas typical Malay clothing in MIN 2 Sambas is worn every Friday acculturated with koko clothing or Muslim student clothing.

Culture of dress in social life has its own values that are believed by a group of people. The value of these beliefs can come from religious teachings or cultural values that were formed from generation to generation by ancestors. Values derived from ancestors are thought creations as a form of noble inheritance that must be maintained by future generations. Values in clothing should be maintained because they can be the pride of the cultural heritage of the people.

Actualization of local cultural wisdom as outlined in the Madrasah Ibtidaiyah Negeri based on elements of Sambas Malay culture is a bay gown and brackets clothes that are integrated with the values of character education. The value of Sambas bay gowns and Sambas Malay brackets can be seen from the standpoint of the function and usage thatis applied in the character development of MIN 2 Sambas students as a means of self-expression and are considered as symbols that are considered sacred in the development of student character values. 
According to Wagiran ${ }^{36}$ Indonesia's character education, local cultural values can be used as the basis for its development. Because local cultural values have universal values of goodness. education that links local wisdom or local culture can improve the noble character of students according to Indonesian culture, namely having character, self-control, and manners.

Based on the results of the field shows that the type of clothing (clothing) Malay Sambas consists of official daily clothing, customs, and brides. Formal daily dress is a general and comprehensive clothing that can be used in formal events, both religious and state or family. Whereas men's formal daily attire is in the form of clothes in brackets called "Teluk Belanga" and "Baju Kurung Cek Weasel". The shape is long-sleeved with trousers enhanced with side cloths and uses headgear in the form of skullcaps and shoes, capal (a type of shoe), or selepar. The buttons of the shirt are five pieces representing the pillars of Islam and the five daily prayers. As for the official women's daily wears, their clothes are brackets and long kebaya (labuh), completed with sarong, shawl (head covering) including ordinary scarves, scope caps, cloaks and hoods of mante, with footwear in the form of sandals and hair covered (bun). ${ }^{37}$

The results showed that MIN 2 Sambas on Friday was dressed in the typical Malay Sambas; male students wear cloak bays like koko while female students wear brackets are Muslim women's clothing. ${ }^{38}$ Judging from the function and manner of wearers in clothing include: (a) clothing is made as a tool to withstand the influence of natural surroundings, (b) clothing as a symbol of excellence and prestige, (c) clothing as a symbol is considered sacred, and (d) clothing as a toolbody jewelry. ${ }^{39}$

Thus the gulf of the bay 'and the brackets in MIN 2 Sambas seen from the function of dress is considered as a symbol of excellence that is possessed by every culture, especially Malay Sambas which is heavily Muslim and clothing is considered to be a sacred and sacred symbol of the shape of the gulf' gown and clothes Sambas Malay brackets give the meaning of politeness in dressing covering the nakedness to avoid the element of evil or in terms of repelling reinforcements.

As revealed from the statement of the head of MIN 2 Sambas states that: "The local cultural values carried out by the Sambas Malay specialties are the bay gowns 'clothes and the Sambas Malay traditional brackets that are used on Friday which are characterized by Islamic clothing ito' (this) is a symbol of Sambas Malay culture from the ge 'marek dolo' era ( long ago) it has been until ito '(now) and remains preserved both in acare peste (party events) weddings, official activities and until ito' (now) there have been ade (there) appeals from the regent of Sambas bahwe (that) the use of the bay and the Sambas Malay brackets are worn by teachers and students. ${ }^{40}$

\footnotetext{
${ }^{36}$ Ida Bagus Putu Arnyana, “Peranan Budaya Bali dalam Mengembangkan Pendidikan Karakter di Sekolah” (2014): hlm. 189.

${ }^{37}$ Suwardi MS, Dari Melayu ke Indonesia; Peranan Kebudayaan Melayu dalam Memperkokoh Identitas dan Jati Diri Bangsa (Yogyakarta: Pustaka Pelajar, 2008).

${ }^{38}$ Siti, “Pakaian Teluk Belanga dan Baju Kurung di Kelas V di Madrasah Ibtidaiyah Negeri 2 Sambas," Oktober 2019.

${ }^{39}$ Koentjaraningrat, Pengantar IImu Antropologi (Jakarta: Rineka Cipta, 2009).

${ }^{40}$ Hamdah, "Pakaian Baju Teluk Belanga dan Baju Kurung di MIN 2 Sambas," Oktober 2019.
} 


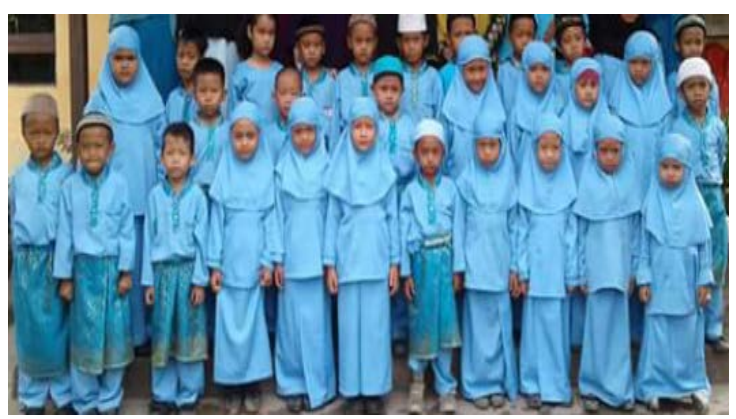

The meaning and usefulness of Malay clothing has a relationship with social norms, religion, customs. Malay clothing is associated with its functions, among others: (a) clothing as a cover for shame, functions as a cover for genitalia, disgrace and shame, (b) clothing as a pick up serves to shape character, shape personality, character so that the user has noble character, (c) clothing as atraditional upholding means describing the noble values contained in the customs and traditions that live in the community. While clothing is used as a repellent, it means dressing properly in a way that prevents the wearer from harm or disaster, (d) clothing upholds the nation with the emblem and values listed in use. ${ }^{41}$

Based on the results of research students are very proud in wearing typical Sambas Malay clothes that show the love of the region. Besides that politeness is also seen that shows a true Muslim. In accordance with the function of Sambas Malay clothing that is clothing as a foster for the function to form character, shape personality, character so that the user has noble character, and clothing as a customary upholder means to describe the noble values contained in the customs and traditions that live in the community.

This is in agreement with Alden, ${ }^{42}$ local products refer to the strategy of associating global with symbolic meanings, values, beliefs and local cultural norms that reflect local cultural identity for local local produk.Based on research findings on the use of bay gowns and Sambas Malay brackets for every teacher and student, the Sambas Regent has been encouraged to wear gowns for men and brackets for women on Fridays with the aim of being accustomed to using Sambas local culture. With the aim to strengthen the Sambas Malay character values, preservation of culture and customs.In line according to Barry, ${ }^{43}$ acculturation involves changes in structure, social institutions, and cultural practices. At the individual level, it involves changes in one's behavior. This change occurs through a long-term process that occurs continuously as long as there is interaction between cultural groups. This process creates cultural adaptations such as language learning, sharing food preferences, and adopting traditional clothing and social interaction between groups.

\footnotetext{
${ }^{41}$ Muhammad Bushar, Pokok-Pokok Hukum Adat (Jakarta: Pradnya Paramita, 2000).

${ }^{42}$ Dongmei Li, et.al., "Culturally Polite Communication: Enhancing the Effectiveness of the Localization Strategy," Journal Of CrossCultural Psychology 51, No. 1 (January 2020): 49-69.

${ }^{43}$ Herwin Sutrisno, et.al., "Living in Harmony: Acculturation of Balinese and Dayak Ngaju Cultures in Basarang Jaya Village, Central Kalimantan," Jurnal IImiah Peuradeun 7, No. 3 (2019): 401-412.
} 
Viewed in terms of symbols with religious values about the culture of clothes, according to Geertz ${ }^{44}$ explains about the definition of religion in five sentences about the definition of religion according to Geertz:(a) system of symbols which acts to (b) establish powerful, pervasive, and longlasting moods and motivations in men by (c) formulating conceptions of a general order of existence and (d) clothing these concepts with such an aura of factuality that (e) the moods and motivations seem uniquely realistic. (a) a symbol system that acts to (b) build a strong, pervasive, and durable mood and motivation in men by (c) formulating the conception of the general order of existence and (d) clothing this conception with such an aura of factuality that (e) the mood and motivation seem uniquely realistic.

Based on the meaning of Geertz's statement that through the meaning of the clothes of the bay gown and the brackets as an introduction to the symbol that has the meaning of character values with a sense of love for their own area and has a sense of modesty in dressing. The meaning of dressing on the Malays can show the identity of the Malays themselves, reflecting the status of someone like a king, hulubalang, ordinary people, reflecting the identity and personality of the Malays, as a symbol of the nobleness of the whole society that shows values as human beings with civilization.

The majority of the Malay Sambas population is Muslim. This religious value is not just something that is inherent on the outside, but has beeninternalized into every community activity. Every case is always associated with religious values. Even in every traditional event, religious aspects are always visible through the reading of bismillah or recitation to the Prophet Muhammad. These religious values also shape unwritten norms in society. As an example, how should men and women interact and how is the attitude of a Malay in carrying out his various obligations. ${ }^{45}$

The view of the bay clothes of men's clothing and women's clothing brackets worn in Madrasah Ibtidaiyah Negeri 2 in Sambas Regency have their own significance for teachers, students and madrassas to instill the value of the character of the love of the region which must be maintained so as not to be lost because it is swallowed by globalizationflow. The tendency to dress in bay gowns and brackets has a positive impact on pride and confidence by wearing the characteristics of the Sambas Malay dress on elementary school level students. The bay gown and the brackets have long been held in Madrasah. This is in accordance with the code of ethics of Madrasah Ibtidaiyah Negeri which is a school characterized by Islam with polite and polite clothing so that the use of bay gowns and clothes brackets is very compatible with Madrasa culture and local culture of the religious Sambas Malay community.

According to Sumardjo, ${ }^{46}$ culture affects the birth of one's creativity. One has to condition where he is born. The place where he is born will influence his actions, deeds and works. Based on the above statement according to the level of elementary school children have a relationship in dress according to

\footnotetext{
${ }^{44}$ Clifford Geertz, Tafsir Kebudayaan, Terj. Francisco Budi Hardiman (Yogyakarta: Kanisius, 1992).

${ }^{45}$ Purniadi Putra, "Implementasi Pendidikan Karakter: Integrasi Lagu Melayu Sambas dalam Pembelajaran pada MIN Kabupaten Sambas" 16 (2019): 88.

${ }^{46}$ Abdul Rahman Prasetyo and Mohammad Makmun Qomar, “Nilai-Nilai Kearifan LokaL (Local Genius) sebagai Penguat Karakter Bangsa pada Ragam Hias Lamin Adat Pemung" (2019): 51.
} 
psychological development in the level of feeling more sensitive children. Feelings of shame and pride give effect to the child's view of the individual so that the child's awareness is higher in adapting about emotions to culture. ${ }^{47}$ According to Ismail ${ }^{48}$ the Malay people dressed as part of a traditional tradition symbolically symbolic of the greatness of the royal attire. Thus clothes have a social meaning that involves intrinsic aesthetic values. The tradition of decorating not only means personal excitement, but has been based on spiritual needs. Thus, the bay gown and the brackets used by the Madrasah Ibtidaiyah level children in character education will provide indirect learning through the symbols of the meaning of the clothes indicating their personal identity.

\section{Implications of the Meaning of the Sambas Malay Dress on student character education}

Clothing is a communication medium It is important that the message depends on dressinga number of variables, such as cultural background and life experiences. ${ }^{49}$ The students 'use of bay gowns and brackets is a symbolic meaning from generation to generation and has social interaction in the language ofcommunication in shaping the character of students' souls through gowns and Sambas Malay brackets. The use of clothing from each individual has its own features that have an impact on value. The clothes of the gulf and the brackets have a high religious and social value from the religious aspect. The clothes have the decency to cover the genitals while the social aspects have the same characteristics.

Based on the research findings on the clothes of the gulf bay and Sambas Malay brackets that are applied in MIN 2 Sambas Regency can be seen from the table below:

\begin{tabular}{|c|c|c|}
\hline Characteristic & The meaning & Character \\
\hline $\begin{array}{l}\text { The bay gown has a long } \\
\text { sleeved shirt with long } \\
\text { pants for boys }\end{array}$ & $\begin{array}{l}\text { Having sacredness means } \\
\text { a principle of protection is } \\
\text { implied in relation to } \\
\text { aspects of life }\end{array}$ & Have a religious attitude \\
\hline $\begin{array}{l}\text { Headgear in the form of } \\
\text { skull cap or skullcap }\end{array}$ & $\begin{array}{l}\text { As a complement to } \\
\text { traditional Sambas Malay } \\
\text { clothes to attend } \\
\text { meetings, or parties }\end{array}$ & $\begin{array}{l}\text { Symbols that indicate } \\
\text { religious and social }\end{array}$ \\
\hline $\begin{array}{l}\text { There are five buttons } \\
\text { on the shirt }\end{array}$ & $\begin{array}{l}\text { Five fruits symbolize the } \\
\text { pillars of Islam and five } \\
\text { daily prayers }\end{array}$ & Religious \\
\hline $\begin{array}{l}\text { Shirt brackets for } \\
\text { women }\end{array}$ & $\begin{array}{l}\text { Religious symbolism as a } \\
\text { dignified outfit in } \\
\text { covering genitalia }\end{array}$ & $\begin{array}{l}\text { Religious, Appreciating } \\
\text { achievements (respecting } \\
\text { the traditions and work of } \\
\text { the Sambas Malay } \\
\text { community }\end{array}$ \\
\hline
\end{tabular}

\footnotetext{
${ }^{47}$ Soetjiningsih, Perkembangan Anak; Sejak Pembuahan sampai dengan Kanak-Kanak Akhir.

${ }^{48}$ Ahadi Sulis Susiawan, "Peran Muhakam dalam Adat Perkawinan sebagai Representasi Adab dan Etika Melayu Sambas," Litera 15, No. 2 (November 29, 2016): 351-365.

${ }^{49}$ Netty Lisdiantini, “Peranan Fashion dan Pakaian sebagai Komunikasi Identitas Sosial," Jurnal Manajemen 3 (2019): 7.
} 
Based on the above table, the bay gowns and the Sambas Malay brackets worn by MIN 2 Sambas students have the characteristics of being long-sleeved with trousers and side cloths and using a skullcap or skullcap as a complement to the traditional Sambas Malay clothes to attend meetings or a party has religious and social meaning. While the 5 pieces of shirt buttons on the Sambas Malay gulf shirt means symbolizing the pillars of Islam and the five daily prayers with religious characters that show obedience in carrying out the 5 times prayer service. As for the official women's daily wears, their clothes are brackets and long kebaya (labuh), completed with sarong, shawl (head covering) including ordinary scarves, scope caps, cloaks and hoods, with footwear in the form of shoes and hair covered (bun) ) with the meaning of religious symbolism as a dignified outfit in covering religious genitalia, an award that respects the traditions and work of the Sambas Malay community.

Costumes not only show ethnic characteristics, but also social and marital status, age and wealth of the wearer and tradition. Maybe every day our lives forget about folk costumes, but this does not mean that it is not part of our history. Because of the cultural heritage attitude towards nature, it is the same as showing our personality and our inner world. The importance of local cultural clothing serves as a valuable glue. Traditional costumes are getting more and more importance these days. They are nothing more than identities; they have become bridges, joining people with a unique heritage. ${ }^{50}$ In the book written by Malcolm, ${ }^{51}$ it is explained that clothes can function as a means of communicating identities, customs, and individual characteristics of their use. A person's dress style is influenced by many things such as culture, values inherited by community groups as well as family, environment, media, fashion trends, and personal character.

\section{E. Conclusion}

The results of this study concluded that with the existence of local wisdom through the use of the Melayu Sambas clothing, students could gain direct experience in the use and meaning of selfidentity. The use of typical Malay Sambas clothing that is applied every day at school will foster a sense of self-confidence and love for the region itself. In addition, the values of character education will be embedded automatically with the Sambas Malay habituation. The distinctive feature of the Sambas Malay clothing has a sacred value in its religious form from the aspect of life, besides that it has a relevant religious value for now in warding off the era of globalization. This study has implications for the value of character education and fostering local culture in an integrated manner in everyday life experienced by elementary level students.

\footnotetext{
${ }^{50} E S$ Mūžizglītībasprogrammas, "Comenius DaudzpusējaisProjekts, the Treasure Chest and ICT or ICT in Reading and Writing" (n.d.).

${ }^{51}$ Fatjri NurTajuddin, "Cultural and Social Identity in Clothing Matters 'Different Cultures, Different Meanings"” (2018): 21.
} 


\section{F. References}

Ahmad, Kamaruzzaman Bustamam. "Educational Practice: Lessons to be Learned from Madrasah and Religious Schools in Contemporary Southeast Asia." Indonesian Journal of Islam and Muslim Societies 5, no. 1 (June 1, 2015): 29. Accessed January 9, 2020. http://ijims.iainsalatiga.ac.id/index.php/ijims/article/view/256.

Alkadri. Bunga Rampai Seni, Budaya \& Sejarah Pejuang Sambas. Pontianak: TOP Indonesia, 2017.

Arnyana, Ida Bagus Putu. "Peranan Budaya Bali dalam Mengembangkan Pendidikan Karakter di Sekolah" (2014): 11.

Awad, Faizah Binti. "Muslim Cultural Identity and Attitude Change among Tolakinese Comunity in Kendari." Journal of Indonesian Islam 10, no. 2 (December 1, 2016): 355. Accessed January 17, 2020. http://jiis.uinsby.ac.id/index.php/Jlls/article/view/351.

Buseri, Kamrani. Dasar, Asas dan Prinsip Pendidikan Islam. Banjarmasin: IAIN Antasari, 2014.

Bushar, Muhammad. Pokok-Pokok Hukum Adat. Jakarta: Pradnya Paramita, 2000.

Chris, Barker. Cultural Studies: Teori Dan Praktik. Terj. Nurhadi. Yogyakarta: Kreasi Wacana, 2006.

Creswell, John W. Qualitative Inquiry \& Research Design Choosing Among Five Approaches. London: Sage Publications, 2007.

Djamudin dkk. "Kajian dan Pengembangan Pembinaan Pendidikan pada Madrasah: Studi Kebijakan Pembinaan Madrasah Era Desentralisasi dan Otonomi Daerah." EDUKASI: Jurnal Penelitian Pendidikan Agama dan Keagamaan 5, no. 3 (2017): 68-75.

Erihadiana, Mohamad. "The Implementation of Islamic Local Content in Building Character Education at Junior High Shcool Al Amanah Bandung." Jurnal Pendidikan Islam 4, no. 2 (January 25, 2019): 4150. Accessed January 17, 2020. https://journal.uinsgd.ac.id/index.php/jpi/article/view/3812.

ES Mūžizglītīibasprogrammas. "Comenius Daudzpusējais Projekts, the Treasure Chest and ICT or ICT in Reading and Writing" (n.d.).

Geertz, Clifford. Tafsir Kebudayaan, Terj. Francisco Budi Hardiman. Yogyakarta: Kanisius, 1992.

Hamdah. “Pakaian Baju Teluk Belanga dan Baju Kurung Di MIN 2 Sambas,” Oktober 2019.

Hamid, Abdullah. Pendidikan Karakter Berbasis Pesantren; Pelajar dan Santri dalam Era IT \& Cyber Culture. Surabaya: IMTIYAZ, 2017.

Hand, Michael. "Moral Education and the Justification of Basic Moral Standards: Replies to Clayton, Stevens and D'Olimpio." Journal of Moral Education 48, no. 4 (October 2, 2019): 529-539. Accessed January 9, 2020. https://www.tandfonline.com/doi/full/10.1080/03057240.2019.1626704.

Handayani, Trisna, EttySoesilowati, and Agustinus Sugeng Priyanto. "Student Character Buliding Reconstruction Junior High School in District Galesong Takalar Based Values National Culture." Journal of Educational Social Studies 7, no. 2 (2018): 116 - 122.

Hermansyah. Melayu dan Islam Borneo. Pontianak: IAIN Pontianak, 2015.

Herwin Sutrisno, Gagoek Hardiman, E.E. Pandelak, and Theresia Susi. "Living In Harmony: Acculturation of Balinese and Dayak Ngaju Cultures in Basarang Jaya Village, Central Kalimantan." Jurnal Ilmiah Peuradeun 7, no. 3 (2019): 401-412. 
Junaedi, Mahfud, and Fatah Syukur. "Moral Education in Japanesse School a Model for Improving Character Education in Indonesia." Analisa Journal of Social Science and Religion 2, no. 1 (2017): 23-40.

Kementerian Pendidikan Nasional Badan Penelitian dan Pengembangan Pusat Kurikulum. Pengembangan Pendidikan Budaya dan Karakter Bangsa. Jakarta: Kementerian Pendidikan Nasional, 2010.

Koentjaraningrat. Pengantar IImu Antropologi. Jakarta: Rineka Cipta, 2009.

Li, Dongmei, Robert Kreuzbauer, Chi-yue Chiu, and Hean Tat Keh. "Culturally Polite Communication: Enhancing the Effectiveness of the Localization Strategy." Journal of Cross-Cultural Psychology 51, no. 1 (January 2020): 49-69. Accessed January 9, 2020. http://journals.sagepub.com/doi/10.1177/0022022119893464.

Lickona, Thomas. Thomas Lickona, Educating for Character; Mendidik untuk Membentuk Karakter. Jakarta: Bumi Aksara, 2015.

Lisdiantini, Netty. "Peranan Fashion dan Pakaian sebagai Komunikasi Identitas Sosial." Jurnal Manajemen 3 (2019): 7.

Maisyanah, and Lilis Inayati. "Internalisasi Nilai-Nilai Pendidikan Agama Islam pada Tradisi Meron." Edukasia: Jurnal Penelitian Pendidikan Islam 13, no. 2 (2018): 287-308.

MS, Suwardi. Dari Melayu ke Indonesia; Peranan Kebudayaan Melayu dalam Memperkokoh Identitas dan Jati Diri Bangsa. Yogyakarta: Pustaka Pelajar, 2008.

Muntansyir, Rizal. Kearifan Lokal Masyarakat Melayu dalam Tinjauan Filosofis, Legenda Rakyat, Filosofis Air, dan Tradisi. Yogyakarta: Fakultas Filsafat, Universitas Gadjah Mada, 2016.

Nata, Abuddin. Sosiologi Pendidikan Islam. Jakarta: PT Raja Grafindo Persada, 2014.

Omar, Endang Susilawati and Asmah Haji. "Makna Sosial dalam Kata Panggilan: Kajian Etnografi Komunikasi dalam Komuniti Bahasa Melayu Sambas." Social Meaning in Address Form 28, no. 1 (2011).

Peratuan Presiden. "Peraturan Presiden Republik Indonesia Nomor 87 Tahun 2017 Tentang Penguatan Pendidikan Karakter," 2017.

Prasetyo, Abdul Rahman, and Mohammad Makmun Qomar. "Nilai-Nilai Kearifan Lokal (Local Genius) sebagai Penguat Karakter Bangsa pada Ragam Hias Lamin Adat Pemung" (2019): 5.

Purna, I Made. "Local Wisdom of Mbawa Village Society in Building Religious Tolerance." Jurnal Pendidikan dan Kebudayaan 1, no. 2 (2016): 17.

Putra, Purniadi. "Implementasi Pendidikan Karakter: Integrasi Lagu Melayu Sambas dalam Pembelajaran pada MIN Kabupaten Sambas” 16 (2019): 10.

Rasyid, Hatamar. "Nilai-Nilai Kearifan Lokal dalam Pengembangan Pendidikan Karakter di Era Global." EDUGAMA 1, no. 1 (2015): 31.

Siswanto, Siswanto, Karimullah Karimullah, Reni Prasetyawati, and Nurhayati Nurhayati. "Environmental Cultured Education and Its Implication on The Student's Competencies in an Adiwiyata School." Jurnal Cakrawala Pendidikan 38, no. 3 (October 24, 2019): 552-564. Accessed January 16, 2020. https://journal.uny.ac.id/index.php/cp/article/view/23154. 
Siti. "Pakaian Teluk Belanga dan Baju Kurung di Kelas V di Madrasah Ibtidaiyah Negeri 2 Sambas," Oktober 2019.

Skårås, Merethe, Tami Carsillo, and Anders Breidlid. "The Ethnic/Local, the National and the Global: Global Citizenship Education in South Sudan." British Journal of Educational Studies (April 5, 2019): 1-21. Accessed January 2020. https://www.tandfonline.com/doi/full/10.1080/00071005.2019.1598540.

Soetjiningsih, Christiana Hari. Perkembangan Anak; Sejak Pembuahan sampai dengan Kanak-Kanak Akhir. Jakarta: Prenada, 2014.

Sukadari, Sukadari, Suyata Suyata, and Shodiq A. Kuntoro. "Penelitian Etnografi tentang Budaya Sekolah dalam Pendidikan Karakter di Sekolah Dasar." Jurnal Pembangunan Pendidikan: Fondasi dan Aplikasi 3, no. 1 (July 1, 2015): 58-68. Accessed January 17, 2020. https://journal.uny.ac.id/index.php/jppfa/article/view/7812.

Sulissusiawan, Ahadi. "Peran Muhakam dalam Adat Perkawinan sebagai Representasi Adab dan Etika Melayu Sambas." LITERA 15, no. 2 (November 29, 2016): 351-365. Accessed January 17, 2020. https://journal.uny.ac.id/index.php/litera/article/view/11834.

Sunahrowi, Sunahrowi, Anastasia P, and Singgih K. "Religiosity and Local Wisdom in Teaching Cultural Science in Faculty of Languages and Arts of Semarang State University." IBDA : Jurnal Kajian Islam dan Budaya 16, no. 2 (November 1, 2018): 262-275. Accessed January 15, 2020. http://ejournal.iainpurwokerto.ac.id/index.php/ibda/article/view/1686.

Sunandar. "Melayu dalam Tantangan Globalisasi: Refleksi Sejarah dan Berubahnya Sistem Referensi Budaya." Khatulistiwa-Journal of Islamic Studies 5, no. 1 (2015): 60-73.

Tajuddin, Fatjri Nur. "Cultural and Social Identity in Clothing Matters 'Different Cultures, Different Meanings'” (2018): 6.

Vinco, Mitchel, Nana Supriatna, and Agus Mulyana. "The Development of 21st Century Cultural Intelligence through Discovery Learning and First-Person Historical Presentation" (2019): 11.

Watson, Lani. "Educating for Inquisitiveness: A Case against Exemplarism for Intellectual Character Education." Journal of Moral Education 48, no. 3 (July 3, 2019): 303-315. Accessed January 16, 2020. https://www.tandfonline.com/doi/full/10.1080/03057240.2019.1589436.

Wibowo, Agus, and Gunawan. Pendidikan Karakter Berbasis Kearifan Lokal di Sekolah. Yogyakarta: Pustaka Pelajar, 2015.

Widisono, Adrian. "The Local Wisdom on Sasak Tribe Sade Hamlet Central Lombok Regency."Local Wisdom : Jurnal IImiah Kajian Kearifan Lokal 11, no. 1 (January 16, 2019): 42-52. Accessed January 9, 2020. http://jurnal.unmer.ac.id/index.php/lw/article/view/2711.

Yusuf, Syamsu. Psikologi Perkembangan Anak dan Remaja. Bandung: PT Remaja Rosdakarya, 2012. 